\title{
Evaluation of outpatient discharge in patients with cutaneous melanoma
}

\author{
Avaliação da alta ambulatorial em pacientes com melanoma cutâneo
}

Nurimar C. Fernandes ${ }^{1}$; Flauberto de Sousa Marinho ${ }^{1}$

A B S T R A C T

\begin{abstract}
Objective: to evaluate discharge in a group of patients with cutaneous melanoma according to recently established criteria. Methods: we conducted an observational, cross-sectional study with 32 patients at theHospital Universitário Clementino Fraga Filho (HUCFF) / Universidade Federal do Rio de Janeiro (UFRJ), between 1995 and 2013, in the following stages: IA (17 cases, $53.12 \%)$, IB (4 cases, 12.5\%), IIA (3 cases, 9.37\%), IIC (1 case, 3.12\%), IIIB (1 case, 3.12\%), IIIC (3 cases, 9.37\%), melanomas in situ (2 cases, 6.25\%), Tx (1 case, 3.12\%). Results: the follow-up time varied from one to 20 years (stage IA), five to 15 years (stage IB), six to 17 years (stage IIA), 20 years (stage IIC), 23 years (stage IIIB) and 14 to 18 years (stage IIIC). One melanoma in situ (subungueal) was discharged in the fourth year of follow-up and the other was promptly discharged. The Tx melanoma was followed for 12 years. We observed no relapses or recurrences in the period. Conclusion: although a controversial issue, it was possible to endorse the discharge of the patients since our follow-up time had already exceeded the one recommended by the other authors.
\end{abstract}

Key words: Prospective studies. Melanoma. Melanoma/epidemiology. Follow-up studies. Neoplasm staging.

\section{INTRODUCTION}

iterature data show that, among patients with cutaneous melanoma (CM), 75\% detect their own recurrences and $50 \%$ detect their second primary tumors; it is possible that professional monitoring visits are scheduled more often than necessary ${ }^{1.2}$.

The risk of recurrence is highest during the first year of follow-up; reports suggest that recurrence tends to a plateau, with low percentages, after the first ten years ${ }^{3}$. To date, there is no international consensus on the followup time of $\mathrm{CM}^{4-6}$.

Marsden et al. ${ }^{6}$ proposed follow-up times for each of the CM stages based on evidence levels: IA (evidence obtained from meta-analysis of randomized controlled trials or meta-analysis of epidemiological studies); IB (evidence obtained from at least one randomized controlled trial); IIA (evidence obtained from at least one well-designed, nonrandomized, controlled study); IIB (evidence obtained from at least one other type of well designed quasi-experimental study); III (evidence obtained from well-designed descriptive studies, such as comparative studies, correlation studies and case studies); IV (evidence obtained from experts committees' reports or opinions and / or respected authorities' clinical). They then proposed the coming followup periods 6 : IA (one year); IB to IIIA (five years); IIIB and IIIC (ten years).
This study aims to carry out the evaluation of discharge in a group of patients with cutaneous melanoma in accordance with the criteria adopted in the Dermatology Service of the Clementino Fraga Filho University Hospital, Federal University of Rio de Janeiro (HUCFF/UFRJ).

\section{METHODS}

We used a multidisciplinary protocol ${ }^{7,8}$ to evaluate 32 patients with cutaneous melanoma in the Dermatology Service at HUCFF / UFRJ, between 1995 and 2013.

Histopathological Staging - Excisional biopsy is the technique of choice to confirm the clinical suspicion of melanoma; incisional punch biopsy is indicated in lesions located on the face, hands, feet and subungual region, with diameter greater than $1.5 \mathrm{~cm}$ or in those in which an excisional biopsy would demand an extensive procedure. The Breslow thickness in the histopathological examination of the specimen (excisional biopsy) defines the optimal margins: $d$ " $1 \mathrm{~mm}(1 \mathrm{~cm}$ margin) and $>1 \mathrm{~mm}$ ( $2 \mathrm{~cm}$ margin), establishing the need for re-excision to expand the margins. Breslow thickness in incisional biopsy is considered temporary. Clinical staging - A) search for evidence of metastatic disease: fever, headache, anemia, weight loss, bone pain, neurological and respiratory

1. Dermatology Service, Clementino Fraga Filho University Hospital, Federal University of Rio de Janeiro, Rio de Janeiro - RJ, Brazil. 
signs and symptoms. B) physical examination of the skin (transit metastasis: lesions in the lymph drainage area, more than $5 \mathrm{~cm}$ distant from the origin of the primary tumor; satellitosis - lesions around the tumor at a $5 \mathrm{~cm}$ radius $\mathrm{C}$ ) physical examination of regional lymph nodes: Impalpable (clinically hidden) - tomographic evaluation and / or ultrasound of the lymph node is performed when doubts arise on palpation; palpable: macrometastasis, clinically detectable, is confirmed by therapeutic lymph node dissection; the commitment is classified according to the number of metastatic lymph nodes, 1, 2-3 and e" 4 being the cutt-off limits. D) general physical exam: liver, spleen and especially the central nervous system; and laboratory tests - in the absence of signs and symptoms of metastasis: blood count, ESR, glucose, urea, creatinine and lactate dehydrogenase (LDH), liver function tests, $x$ ray of pleuropulmonary fields; in patients with metastases detected by clinical examination, the following tests are added: CT scan of chest, abdomen, pelvic cavity, and bone scintigraphy. Skeletal radiography is added if the bone scan reveals changes.

\section{RESULTS}

We evaluated 32 patients, predominantly female (21) and white (28), aged between 40 and 70 years old (29). The lesions were most commonly found in the head (8 cases) and trunk (11) (Table 1).

The cases were grouped into the following stages: IA (17 cases, 53.12\%); IB (4 cases, 12.5\%); IIA (3 cases, 9.37\%); IIC (1 case, 3.12\%); IIIB (1 case, 3.12\%); IIIC (3 cases, 9.37\%) (Tables 2 and 3).

Outpatient follow-up ranged from one to 20 years (stage $I A$ ), five to 15 years (stage $I B$ ), six to 17 years (stage IIA), 20 years (stage IIC), 23 years (stage IIIB) and 14-18 years (stage IIIC).

\section{DISCUSSION}

The routine for $\mathrm{CM}$ used to be based in the staging and follow-up indefinitely, except for in situ melanomas that were discharged (Table 2). In 2013, the retrospective analysis showed: the Breslow thickness was not determined $(\mathrm{Tx})$ in one patient. In some circumstances, this evaluation index is partially damaged or becomes less accurate. The AJCC 2002/2009 does not define the conduct in melanomas Tx $x^{9}$. Follow-up lasted 12 years (Table 2).

According to our protocol ${ }^{7.8}$, those with in situ melanoma (isM) are discharged, a conduct also recommended by Marsden et al. ${ }^{6}$. We observed two such patients (6.25\%): one white, 46 years old, with a lesion located on the back; and one black, 40 years old, with dystrophy and overall darkening of the nail plate of the second right finger (subungual melanoma), evolving from a striated melanonychia; this patient underwent biopsy of the proximal nail fold and nail matrix. Amputation was indicated, since the excision with safety margins and the preservation of the finger functionality are not always feasible. The surgical specimen revealed melanoma in situ. Although our conduct in patients with melanoma in situ is discharge, we followed the observations of Tan et al. ${ }^{10}$, who studied the initial stage of the subungual melanoma in 121/124 cases: $11(9 \%)$, stage $0 ; 16(14 \%)$, stage I; 50 (41\%), stage II; 30 (32\%), stage III; and five (4\%) stage IV. Nine of the 11 patients with isM were followed on average for 35 months. Our patient was discharged on the fourth year of monitoring (Table 2). Tan et al. ${ }^{10}$ pointed out that the accurate measurement of Breslow thickness may be difficult in acral melanoma and, in particular, the subungual melanoma, since the healthy nail matrix does not have a granular layer and the subcutaneous fat may be absent in the subungual area.

Among the 17 stage IA patients, five had new isM after one, two, four, six and 11 years of the initial

Table 1 - Distribution of cutaneous melanoma by age group, sex, color and location.

\begin{tabular}{|c|c|c|c|c|c|c|c|c|c|c|}
\hline \multirow[t]{2}{*}{ Age Group } & \multicolumn{2}{|c|}{ Gender } & \multicolumn{2}{|c|}{ Color } & \multirow[b]{2}{*}{ Head } & \multirow[b]{2}{*}{ Trunk } & \multicolumn{2}{|c|}{ Location } & \multirow[b]{2}{*}{ Foot } & \multirow[b]{2}{*}{ Hand } \\
\hline & $\mathrm{F}$ & M & W & NW & & & $\begin{array}{l}\text { Upper } \\
\text { Limb }\end{array}$ & $\begin{array}{l}\text { Lower } \\
\text { Limb }\end{array}$ & & \\
\hline $20-30$ years old & - & 1 & 1 & - & - & 1 & - & - & - & - \\
\hline $31-40$ years old & 2 & - & 1 & 1 & 1 & 1 & - & - & - & - \\
\hline $41-50$ years old & 4 & 4 & 7 & 1 & 2 & 3 & - & 2 & - & 1 \\
\hline $51-60$ years old & 6 & 2 & 6 & 2 & 1 & 2 & 1 & 1 & 3 & - \\
\hline $61-70$ years old & 6 & 1 & 7 & - & 3 & 1 & 1 & 1 & 1 & - \\
\hline $71-80$ years old & 2 & 3 & 5 & - & 1 & 2 & 1 & - & 1 & - \\
\hline $81-90$ years old & 1 & - & 1 & - & 0 & 1 & - & - & - & - \\
\hline TOTAIS & 21 & 11 & 28 & 4 & 8 & 11 & 3 & 4 & 5 & 1 \\
\hline
\end{tabular}

Source: HUCFF/UFRJ (1995-2013)

Conventions: $W$ - white; NW - not white; F - female; $M$ - male. 
Table 2 - Distribution of cases according to staging and follow-up (HUCFF).

\begin{tabular}{|c|c|c|c|}
\hline Stage & $\begin{array}{l}\text { Number } \\
\text { of cases }\end{array}$ & $\begin{array}{l}\text { Outpatient Follow-up } \\
\text { Routine }\end{array}$ & Time \\
\hline Tx & 1 & - not-defined & 12 years \\
\hline Tis & 2 & $\begin{array}{l}\text { - resection with a } 0.5 \mathrm{~cm} \text { margin } \\
\text { - discharge }\end{array}$ & $\begin{array}{l}\text { Discharge } \\
4 \text { years }\end{array}$ \\
\hline I A & 17 & $\begin{array}{l}\text { - Resection: } 1.0 \mathrm{~cm} \text { margin } \\
\text { - dermatological and lymph node examination: every six months (first two years) } \\
\text { and then annually }\end{array}$ & $\begin{array}{l}1,2,4,5,7,10,12 \\
14,15,16,20 \text { years }\end{array}$ \\
\hline I B & 4 & $\begin{array}{l}\text { - Resection: 2,0 cm margin } \\
\text { - Dermatological and lymph node examination: every two months (two years) } \\
\text { and thereafter, every six months } \\
\text { - X-ray of chest and liver function tests: every six months (two years) } \\
\text { and then annually }\end{array}$ & $5,5,11,15$ years \\
\hline$\| A$ & 3 & I B & $6,15,17$ years \\
\hline$\| C$ & 1 & $\begin{array}{l}\text { - Resection: 2,0 cm margin } \\
\text { - Dermatological and lymph node examination: every two months (two years) } \\
\text { and thereafter, every six months } \\
\text { - X-ray of chest and liver function tests: every six months (two years) } \\
\text { and then annually }\end{array}$ & 20 anos \\
\hline III B & 1 & $\begin{array}{l}\text { - Clinical examination every four months } \\
\text { - X-ray of chest and liver function tests: every six months } \\
\text { - Imaging tests targeted to the region where there is relapse } \\
\text { every four months } \\
\text { - Resection of limited locoregional and visceral metastases } \\
\text { - individualized chemotherapy }\end{array}$ & 23 years \\
\hline III C & 3 & III B & 14,18 years \\
\hline
\end{tabular}

diagnosis, respectively. The follow-up ranged from one to 20 years (Table 2). One patient (stage IB) submitted a new cutaneous melanoma two years after the first diagnosis. The four patients with stage IB were followed for five years (Table 2).

Considering the three patients included in the IIA stage, there were two acral lentiginous melanomas and one located in the chest. One of the acral lentiginous melanomas showed a neurotropic histological type - white female patient, 80 years old, left plantar region, evolution of 30 years. The neurotropic variant is composed of spindle cells with a pattern like a neuroma and tendency for circumferential distribution around small nerve fibers in the deep dermis and hypodermis. As a unique clinicopathological variant, it presents in the form of a pigmented or amelanotic nodule of rapid growth. The follow-up ranged from six to 17 years (Table 2).

One IIC patient(white, male, 50 years old, with nodular melanoma in his left knee and positive left inguinal sentinel lymph node) underwent lymph node dissection and then followed for 20 years without recurrence or relapse (Table 2). One IIIB patient (white, male, 26 year old, with nodular melanoma on the back) was followed for 23 years without recurrence or relapse (Table 2).

Stage III melanoma is associated with high risk of recurrence and mortality. A retrospective study showed five-year survival without disease in the percentages of $63 \%$ (IIIA) and 32\% (IIIB) ${ }^{11}$. Early recurrence sites were: local / regional transit $(28 \%)$, regional lymph node $(21 \%)$ and systemic (51\%).

Three patients were classified as IIIC: a) nonwhite, female, 63 years old, with acral lentiginous melanoma in the left plantar region, positive sentinel lymph node, submitted to inguinal lymph node dissection, monitored for 14 years without recurrence or relapse (Table 2); b) white, male, 76 years old, melanoma in the sternal region with metastatic lymph node in the right axillary region; lymph node dissection, followed for 14 years without recurrence or emergence of a new tumor (Table 2); c) white, male, 51 year old, acral lentiginous melanoma on the right heel. He showed two lymph node metastasis in the right inguinal lymph node chain and one in the right aortoiliac chain, having been followed for 18 years, without recurrence or appearance of new tumors (Table 2). 
Table 3 - $\quad$ Staging of cutaneous melanoma (AJCC 2002/2009)9.

\begin{tabular}{|c|c|c|c|}
\hline Stage & Tumor $(\mathrm{T})$ & Lymph nodes (N) & Metastasis (M) \\
\hline I A & $\begin{array}{l}<1 \mathrm{~mm} \\
\text { Clark II/III } \\
\text { without histological ulceration }\end{array}$ & $\varnothing$ & $\varnothing$ \\
\hline I B & $\begin{array}{l}<1 \mathrm{~mm} \\
\text { Clark IVN } \\
\text { with histological ulceration } \\
1,01-2 \mathrm{~mm} \\
\text { without histological ulceration }\end{array}$ & $\varnothing$ & $\varnothing$ \\
\hline$\| A$ & $\begin{array}{l}1,01-2 \mathrm{~mm} \\
\text { with histological ulceration } \\
2,01-4 \mathrm{~mm} \\
\text { without histological ulceration }\end{array}$ & $\varnothing$ & $\varnothing$ \\
\hline$\| B$ & $\begin{array}{l}2,01-4 \mathrm{~mm} \text { with ulceration } \\
>4 \mathrm{~mm} \text { without ulceration }\end{array}$ & $\varnothing$ & $\varnothing$ \\
\hline$\| C$ & $>4 \mathrm{~mm}$ with histological ulceration & $\varnothing$ & $\varnothing$ \\
\hline$I I I A$ & $\begin{array}{l}<1 \mathrm{~mm} \text { a }>4 \mathrm{~mm} \text { without ulceration } \\
<1 \mathrm{~mm} \text { a }>4 \mathrm{~mm} \\
\text { Without ulceration }\end{array}$ & $\begin{array}{c}\varnothing \\
1 \text { micrometastasis } \\
1 \text { a } 3 \text { micrometastases }\end{array}$ & $\begin{array}{l}\varnothing \\
\varnothing \\
\varnothing\end{array}$ \\
\hline III B & $\begin{array}{l}<1 \mathrm{~mm} \text { a }>4 \mathrm{~mm} \text { with or without histological } \\
\text { ulcerationtransit metastasissatellitosis }\end{array}$ & $\begin{array}{l}1 \text { a } 3 \text { micrometastases } \\
2 \text { a } 3 \text { macrometastases }\end{array}$ & $\varnothing$ \\
\hline III C & $\begin{array}{l}<1 \mathrm{~mm} \text { a }>4 \mathrm{~mm} \\
\text { histological ulcerationany thick } \\
\text { nesssatellitosistransit metastasis }\end{array}$ & $\begin{array}{l}\text { Confluent lymph nodes } \\
1 \text { macrometastasis } \\
2 \text { to } 3 \text { or more than } \\
4 \text { macrometastases }\end{array}$ & $\varnothing$ \\
\hline
\end{tabular}

Local recurrences are defined as tumor relapse within 3 to $5 \mathrm{~cm}$ from the primary closure or graft and are considered to be rare (3.2\%). The ulceration and the thickness of the primary tumor, as well as the location in the head and neck, are considered predisposing factors ${ }^{7}$.
Although the subject is controversial and our monitoring time exceeded the period adopted by some centers $^{6,12}$, we concluded that it was possible to endorse the discharge of patients in stages IA, IB, IIA, IIC, IIIB and IIIC.

\section{R E S U M O}

Objetivo: realizar a avaliação da alta em um grupo de pacientes com melanoma cutâneo de acordo com critérios recentemente estabelecidos. Métodos: estudo observacional de corte transversal de 32 pacientes com melanoma cutâneo atendidos no HUCFF/UFRJ, entre 1995 e 2013, nos seguintes estágios: IA (17 casos/53,12\%), IB (4 casos/12,5\%), IIA (3 casos/9,37\%), IIC (1 caso/3,12\%), IIIB (1 caso/3.12\%), IIIC (3 casos/9,37\%), melanomas in situ (2 casos/6,25\%), Tx (1 caso/3,12\%). Resultados: o tempo de seguimento ambulatorial variou de um a 20 anos (estágio IA), cinco a 15 anos (estágio IB), de seis a 17 anos (estágio IIA), 20 anos (estágio IIC), 23 anos (estágio IIIB) e de 14 a 18 anos (estágio IIIC). O melanoma Tx foi acompanhado por 12 anos, um melanoma in situ teve alta imediata e outro, subungueal, permaneceu em acompanhamento por quatro anos. Não foram observadas recidivas ou recurrências. Conclusão: houve adequação do procedimento de alta nos estágios IA, IB, IIA, IIC, IIIB e IIIC.

Descritores: Estudos prospectivos. Melanoma. Melanoma/epidemiologia. Seguimentos. Estadiamento de neoplasias. 


\section{REFERENCES}

1. Turner RM, Bell KJ, Morton RL, Hayen A, Francken AB, Howard K, et al. Optimizing the frequency of follow-up visits for patients treated for localized primary cutaneous melanoma. J Clin Oncol. 2011;29(35):4641-6

2. Sondak VK, Leachman SA. Individualizing follow-up for patients with early-stage melanoma. J Clin Oncol. 2011;29(35):4606-8.

3. Francken $A B$, Accortt NA, Shaw HM, Colman MH, Wiener $M$, Soong SJ, et al. Follow-up schedules after treatment for malignant melanoma. Br J Surg. 2008;95(11):1401-7.

4. Garbe C, Peris K, Hauschild A, Saiag P, Middleton M, Spatz A, et al. Diagnosis and treatment of melanoma. European consensusbased interdisciplinary guideline-Update 2012. Eur J Cancer. 2012;48(15):2375-90.

5. Dummer R, Guggenheim M, Arnold AW, Braun R, von Moos R; Project Group Melanoma of the Swiss Group for Clinical Cancer Research. Updated Swiss guidelines for the treatment and followup of cutaneous melanoma. Swiss Med Wkly. 2011;141:w13320.

6. Marsden JR, Newton-Bishop JA, Burrows L, Cook M, Corrie PG, Cox NH, et al. Revised U.K. guidelines for the management of cutaneous melanoma 2010. Br J Dermatol. 2010;163(2):238-56.

7. Fernandes NC, Calmon R, Maceira JP, Cuzzi T, Silva CSC. Melanoma cutâneo: estudo prospectivo de 65 casos. An Bras Dermatol. 2005;80(1):25-34.
8. Fernandes NC, Calmon R. Melanoma cutâneo: estudo prospectivo de 42 casos. 2010;86(6):1233-5.

9. Balch CM, Gershenwald JE, Soong SJ, Thompson JF, Atkins MB, Byrd DR, et al. Final version of 2009 AJCC melanoma staging and classification. J Clin Oncol. 2009;27(36):6199-206.

10. Tan KB, Moncrieff M, Thompson JF, McCarthy SW, Shaw HM, Quinn MJ, et al. Subungueal melanoma: a study of 124 cases highlighting features of early lesions, potential pitfalls in diagnosis, and guidelines for histologic reporting. Am J Surg Pathol. 2007;31(12):1902-12

11. Romano E, Scordo M, Dusza SW, Coit DG, Chapman PB. Site and timing of first relapse in stage III melanoma patients: implications for follow-up guidelines. J Clin Oncol. 2010;28(18):3042-7.

12. Leiter $U$, Eigentler TK, Forschner A, Pflugfelder A, Weide B, Held L, et al. Excision guidelines and follow-up strategies in cutaneous melanoma: Facts and controversies. Clin Dermatol. 2010;28(3):3115

Received on 05/042014

Accepted for publication 03/06/2014

Conflict of interest: none.

Source of funding: none.

Address for correspondence:

Nurimar C. Fernandes

E-mail:nurimarfernandes@terra.com.br 